\title{
A ilusão biográfica sobre Machado de Assis e a questão agrária oitocentista no Brasil
}

Resumo: Trata-se aqui de apresentar diferentes aproximações do escritor brasileiro Machado de Assis à questão agrária oitocentista. Vamos discutir sua atuação como chefe da Segunda Seção da Diretoria da Agricultura do Ministério da Agricultura, Comércio e Obras Públicas, assim como sua condição de literato. Apelaremos aos procedimentos relacionados à questão agrária nos quais tomou parte nas duas últimas décadas do Império. Também pretendemos desconstruir uma possível "ilusão biográfica" em torno de sua trajetória, utilizando alguns de seus escritos literários. Almejamos apresentar como, em algumas decisões no funcionalismo público, ele se aproximou e, em outras, se distanciou dos interesses senhoriais.

Palavras-chave: Diretoria da Agricultura, Machado de Assis, propriedade, Brasil império.

\section{La ilusión biográfica acerca de Machado de Assis y el problema agrario en el Brasil del siglo XIX}

Resumen: Este artículo presenta diferentes aproximaciones del escritor Machado de Assis al problema agrario en el Brasil del siglo XIX. Usaremos los documentos firmados por él en el Ministerio de la Agricultura, Comercio y Obras Públicas, así como los escritos literarios de este autor. Apelaremos a los procedimientos asociados al problema agrario firmados por Machado de Assis en las últimas dos décadas del Imperio. Además, se intentará deshacer la "ilusión biográfica" sobre la trayectoria de este escritor; demostrando cómo, en algunos procedimientos, Machado de Assis se aproximó a intereses señoriales, mientras, en otros, estaba en contra de los mismos.

Palabras clave: Junta Directiva de la Agricultura, Machado de Assis, propiedad, imperio brasileño.

\section{The biographical illusion about Machado de Assis and the 19th century Brazilian agrarian issues}

Abstract: This article shows how the Brazilian writer Machado de Assis approached his country's 19th-century agrarian problems. It will consider his work in the Agriculture, Commerce, and Public Work Ministry and his literary writings. It also recurs the administrative procedures from his time in this department and his literary writings. The purpose is to negate a "biographical illusion" related to Machado de Assis' trajectory. We will point out how his administrative decisions related to different ways with slave owners' interests, sometimes favoring them and other times against them.

Keywords: Agriculture Directory, Machado de Assis, property, Brazilian empire.

Cómo citar este artículo: Pedro Parga Rodrigues, "A ilusão biográfica sobre Machado de Assis e a questão agrária oitocentista no Brasil”, Trashumante. Revista Americana de Historia Socia/19 [2022]: 186-207.

DOI: 10.17533/udea.trahs.n19a09

Fecha de recepción: 11 de septiembre 2020

Fecha de aprobación: 8 de abril 2021

Pedro Parga Rodrigues: Doctor en Historia por la Universidade Federal Fluminense. Actualmente realiza estudios posdoctorales en la Universidade Federal Rural do Rio de Janeiro y participa en el Núcleo de Pesquisa Propriedade e suas múltiplas dimensões. ORCID: 0000-0003-4876-9073.

Correo electrónico: pedropargar@gmail.com 


\section{A ilusão biográfica sobre Machado de Assis e a questão agrária oitocentista no Brasil}

Pedro Parga Rodrigues

$\mathrm{T}$

rata-se aqui de apresentar diferentes facetas do escritor carioca José Maria Machado de Assis, em sua relação com a questão agrária oitocentista. Desta forma, desconstruiremos a aparente linearidade sobre a sua trajetória, passível de ser apreendida da leitura de trabalhos acadêmicos que os posicionamentos deste escritor sobre o cativeiro. É importante mencionar que aquelas pesquisas tiveram um papel fundamental na recuperação da agência histórica deste intelectual e de outros agentes subalternos da sociedade imperial brasileira; porém, acabaram deixando de lado momentos em que Machado de Assis foi mais comedido ou acomodado diante das relações sociais e institucionais que experimentou. É por isso que pretendemos ressaltar alguns de seus posicionamentos mais próximos e mais distantes dos interesses dos potentados locais através de dois textos literários de sua autoria e, sobretudo, processos nos quais ele atuou enquanto chefe da Segunda Seção da Diretoria da Agricultura do Ministério da Agricultura, Comércio e Obras Públicas (MACOP).

Machado de Assis ou o "Bruxo do Cosme Velho", como foi apelidado, alcançou o status de uma espécie de patrimônio cultural brasileiro na década de 1930, depois de ter sido alvo de constantes ataques de determinados intelectuais. ${ }^{1}$ Também, exerceu a maior parte de sua atividade literária durante o Período Imperial, em um contexto de escravidão e de uma sociedade extremamente hierarquizada. Ele nasceu em liberdade, sendo filho de pai liberto e mãe açoriana; cresceu como agregado na casa de sua madrinha no Rio de Janeiro; aprendeu a ler e escrever sem ter frequentado espaços de educação formal; conquistou postos no funcionalismo público; escreveu para diversos jornais e trabalhou como crítico teatral, bem como redigiu contos, romances, crônicas, poesias, peças de teatros, um livro técnico sobre a legislação agrária e pareceres administrativos.

1. Hélio de Seixas Guimarães, Machado de Assis, o escritor que nos lê. As figuras machadianas através da crítica e das polêmicas (São Paulo: Editora Unesp, 2017) 73-158; Hélio de Seixas Guimarães, Os leitores de Machado de Assis. O romance machadiano e o público de literatura no século 19 (São Paulo: Nankin / Edusp, 2012) 71-84. 
Mais adiante, em 1873, passou a trabalhar como funcionário público no MACOP; depois, em 1876 foi promovido a chefe da Segunda Seção da Diretoria da Agricultura. Tratava-se da repartição ministerial responsável por aplicar a legislação agrária no Segundo Reinado. Este órgão recebia solicitações de compra de terras de todo Império, decidia sobre os prazos para medição e demarcação dos limites territoriais, opinava sobre conflitos fundiários, bem como solucionava outras demandas relacionadas com a questão fundiária.

Durante sua atuação na Diretoria, Machado de Assis deixou suas assinaturas, pareceres e comentários processuais em diferentes processos administrativos, relacionados com: a gestão de pessoal da sua repartição, solicitações de terras, pedidos de demarcação e medição de limites fundiários, invasão em aldeamentos indígenas, depuração de direitos sobrepostos, disputas envolvendo fontes de água no sertão, etc.

Machado de Assis recebeu diferentes caracterizações de seus biógrafos e pesquisadores. Um dos debates instaurados sobre a sua trajetória versa sobre ele ter sido ou não acomodado diante dos problemas sociais de sua época. Esta discussão foi iniciada ainda em 1897, quando a performance literária e a biografia deste autor foram encaradas pela perspectiva determinista de Silvio Romero. ${ }^{2} \mathrm{O}$ determinismo racial de Romero serviu para criticar os escritos machadianos com base em critérios étnicos. Somente nas décadas de 1950 e 1960, no contexto das lutas por direitos civis norte-americanas, Helen Caldwell percebeu os deboches deste escritor oitocentista à sociedade de sua época. Isso foi possível porque a autora compreendeu a necessidade de desconfiar das assertivas emitidas pelos narradores-personagens pouco confiáveis dos textos machadianos. ${ }^{3}$

Recentemente, trabalhos como os de Sidney Chalhoub, Daniela Silveira, Flávia Cernic, Eduardo Duarte e outros autores têm contribuído para desfazer a leitura sobre a trajetória do literato na qual ele não se posicionaria em oposição à escravidão e demais mazelas de seu tempo. ${ }^{4}$ Estes autores revelam posicionamentos políticos nas diferentes áreas de atuação machadiana: na literatura, jornalismo, funcionalismo público etc. Ademais, demonstram a impossibilidade de afirmar uma essência omissa para Machado de Assis e destacam a faceta crítica aos interesses senhoriais deste literato, enfatizando os posicionamentos do Bruxo do Cosme Velho contrários à escravidão e os seus deboches com relação à classe senhorial. Na literatura machadiana, estes questionamentos ao cativeiro e às perspectivas dos potentados rurais foram comuns; porém, a ênfase na faceta crítica do literato, ao nosso ver, acabou criando uma "ilusão biográfica". ${ }^{5}$ Em alguns

2. Guimarães, Machado de Assis, o escritor 159-212.

3. Guimarães, Machado de Assis, o escritor 159-212.

4. Sidney Chalhoub, Machado de Assis, historiador (São Paulo: Companhia das Letras, 2003); Daniela Magalhães da Silveira, Fábrica de contos: ciência e literatura em Machado de Assis (Campinas: Editora da Unicamp, 2010); Ana Flávia Cernic Ramos, As máscaras de Lélio: política e humor nas crônicas de Machado de Assis (1883-1886) (Campinas: Editora da Unicamp, 2016); Eduardo de Assis Duarte, Machado de Assis afrodescendente (Belo Horizonte: Pallas, 2009).

5. Ilusão biográfica é um conceito do Pierre Bourdieu. Refere-se à tendência de algumas narrativas 
contextos, Machado de Assis debochou da escravidão, das perspectivas senhoriais e da questão agrária oitocentista, mas, em outros, ele se omitiu ou concordou com decisões favoráveis aos interesses senhoriais de seus colegas no funcionalismo público, chegando a favorecer noções de propriedade hegemônicas. Inclusive, foi comum nos pareceres machadianos da Diretoria o recurso à palavra "concordo" seguida da assinatura. O laconismo foi uma marca nos seus escritos oficiais nesta repartição, assim como uma tendência a fugir de controvérsias.

Nossa pesquisa vem tratando sobre os posicionamentos machadianos diante da questão agrária oitocentista; partimos de um tema diferente daqueles estudados pelos autores que ressaltaram a faceta crítica do Bruxo do Cosme Velho. Eles geralmente enfatizaram as galhofas machadianas ao cativeiro.

O ponto de partida dos nossos estudos foi a questão agrária no conto Na Arca: três capítulos (inéditos) das gênesis ( $\mathrm{Na}$ Arca). Nesta paródia à Bíblia, publicada pela primeira vez em 1878 no jornal O Cruzeiro, dois filhos de Noé disputam fronteiras fundiárias, desconsiderando os direitos dos interlocutores e maximizando os seus próprios. O literato escamoteou nos discursos das personagens uma retórica tipicamente senhorial, debochando dos potentados de seu tempo; apresentando desta forma, um posicionamento crítico frente às noções de propriedade senhoriais. Ainda que esperássemos encontrar nos pareceres ministeriais assinados por Machado um tom questionador semelhante ao do referido conto, percebemos uma oscilação nos posicionamentos dele no funcionalismo público. Em alguns momentos, ele, de fato, se opôs aos mandos e desmandos dos potentados rurais ou favoreceu aos pequenos agricultores; mas, em diferentes ocasiões, acabou simplesmente reproduzindo ou se adequando às decisões de seus colegas e/ou favorecendo políticas públicas ligadas ao status quo.

O exercício da atividade como funcionário público, sobretudo de um chefe de seção ministerial, possuía diferenças marcantes com relação a de um literato. As relações sociais internas de cada um destes campos tinham características próprias; isto pode ser um dos fatores de explicação para a dissintonia na prática machadiana nas diferentes experiências profissionais.

Os pareceres dele tinham como interlocutores presidentes do conselho de ministros e os titulares da pasta das mais diversas posições políticas. Estes agentes podiam ser, em alguns momentos, mais propensos às reformas no cativeiro (tal é o caso do Visconde do Rio Branco); ${ }^{6}$ mas, em outras circunstâncias, eram ávidos escravagistas (como Barão de Cotegipe). Além disso, potentados rurais podiam ser partes interessadas nas decisões da Diretoria. Por conseguinte, o chefe de seção ministerial, Machado de Assis, precisava negociar com os valores hegemônicos de seu tempo nas suas decisões administrativas porque, ser expressamente contrário

biográficas de forjar uma aparente continuidade para uma trajetória de vida.Ver Pierre Bourdieu, "A ilusão biográfica", Usos e abusos da história oral, coords. Janaína Amado e Marieta de Moraes Ferreira (Rio de Janeiro: Editora FGV, 2006) 183-191.

6. Angela Alonso, Flores, votos e balas. O movimento abolicionista brasileiro (1868-88) (São Paulo: Companhia das Leras, 2015) 104. 
a ditos valores, poderia resultar na sua demissão; como aconteceu com José do Patrocínio, que perdeu seu posto de amanuense da Secretaria de Polícia por causa de sua militância abolicionista. ${ }^{7}$ Isto porque, no Império, os funcionários públicos não possuíam estabilidade e a maior parte do seu sustento provinha da atividade ministerial. Todo isso, teve um impacto também na literatura machadiana, porque resultou nas seguintes estratégias literárias recorrentes nos textos do "Bruxo do Cosme Velho": a utilização de pseudônimos e o escamotear de críticas à sociedade nos discursos de narradores-personagens com perspectivas próprias. Tratava-se de estratégias para evitar constrangimentos sociais, ${ }^{8}$ porque assim podia realizar seus juízos em um contexto no qual as suas formas de expressão eram controladas pela instabilidade de seu cargo. ${ }^{9}$ Eduardo de Assis Duarte demonstrou como as táticas de dissimulação dos deboches presentes no humor machadiano eram, ao mesmo tempo, uma marca de sua bagagem cultural afrodescendente e um cálculo político do Bruxo do Cosme Velho diante da instabilidade de sua condição de funcionário público. ${ }^{10}$ Duarte, inclusive, nomeou as estratégias discursivas machadianas como "capoeira literária", associando-as ao esporte da tradição afro-brasileira, no qual os praticantes disfarçam seus golpes com floreios e gingados.

Esta estética da dissimulação também foi comum, posteriormente, em sambas escritos com o objetivo de escapar da censura da Ditadura do Estado Novo (19371945). O samba, a capoeira e as músicas deste esporte são partes integrantes da cultura afro-brasileira. Eles compartilham com a literatura machadiana as estratégias de disfarçar seus posicionamentos e/ou golpes.

De qualquer forma, é um fato que Machado de Assis nem sempre adotou um tom crítico com relação às questões fundiárias oitocentistas. Possivelmente, seus posicionamentos mais conservadores resultaram dos constrangimentos aos quais um escritor mulato estava submetido em uma sociedade hierarquizada. Ainda assim, negar esta faceta seria deixar de lado a complexidade deste sujeito histórico. Representaria forjar uma linearidade para sua trajetória, ignorando as diversas

7. Alonso 104.

8. Ramos 47-55.

9. Para Eduardo de Assis Duarte, a "utilização do foco narrativo em primeira pessoa" por Machado seria como uma "ginga verbal do capoeirista, sempre pronto ao disfarce e ao engodo". Este pesquisador demonstra como a dissimulação foi "o caminho escolhido por Machado de Assis, em especial no que diz respeito ao pendor crítico que perpassa seus textos, tanto na crônica como na ficção". Ele ainda nomeia Machado de "um escritor que parece se divertir em brincar de esconde-esconde com seus leitores" e menciona a existência de "narradores tendenciosos, não confiáveis, enganosos" em seus escritos literários. Neste ponto, toma de empréstimo o próprio adjetivo "enganoso" atribuído por John Gledson aos contadores das histórias machadianas. Sobre este assunto, ver Eduardo de Assis Duarte, "A capoeira literária de Machado de Assis", Machado de Assis em Linha 2.3 (2009): 27-32; Silviano Santiago, Uma literatura nos trópicos. Ensaios sobre dependência cultural (Rio de Janeiro: Rocco, 2000) 27-46; Ramos 47-55; Hélio de Seixas Guimarães, "O Machado terra-a-terra de John Gledson”, Novos Estudos - CEBRAP 77 (2007): 265; John Gledson, Por um novo Machado de Assis. Ensaios (São Paulo: Companhia das Letras, 2006) 281.

10. Duarte, “A capoeira literária”27-38. 
nuances e facetas ou ignorar os constrangimentos aos quais Machado esteve submetido e contra os quais reagiu em diversas ocasiões. Desta forma, pretendemos apresentar pelo menos duas facetas desta personagem do Segundo Reinado: uma mais crítica e outra mais acomodada. Para, assim, rompermos com a possível ilusão biográfica sobre sua trajetória.

Com isto, não estamos afirmando que outros autores criaram propositalmente uma aparência de linearidade no percurso machadiano; já que isso pode ter sido um resultado inesperado do ato de fazer frente a outra corrente que apresentava Machado unicamente como acomodado, a consequência de um recorte teórico importante por demonstrar a capacidade dos subalternos agirem como sujeitos conscientes ou, simplesmente, o efeito do foco nas percepções machadianas sobre o cativeiro. De qualquer forma, esses trabalhos tiveram o papel importantíssimo de recuperar a agência histórica da personagem em tela. Seguindo Edward Palmer Thompson, perceberam historicidade da consciência, deixando de procurar no passado noções estáticas pré-determinadas por historiadores do presente. Entretanto, é preciso também indicar a existência de condicionamentos e limites sociais para a atuação do sujeito estudado.

Pode ser que, o foco na questão agrária tenha sido a razão para encontrarmos diferentes lados deste escritor. Também pode ter sido importante, para esta descoberta, a adoção de uma determinada leitura do conceito de agência em Edward Palmer Thompson — na qual a ideia de hegemonia e os aspectos sociais coercitivos não são descartados. ${ }^{11}$ Algumas compreensões sobre os textos do autor marxista inglês propõem que ele teria abandonado completamente os aspectos sistêmicos, mas discordamos destas perspectivas, pois os estudos dele tinham como pano de fundo a formação da classe operária inglesa; no entanto, não debruçaremos aqui sobre estas controvérsias. Inicialmente, imaginávamos que encontraríamos nas fontes ministeriais somente um Machado de Assis crítico à realidade agrária oitocentista e pretendíamos seguir os passos dos estudiosos que ressaltavam a agência histórica deste literato e não abandonamos completamente este caminho; entretanto, as fontes nas quais Machado simplesmente concordava com seus colegas ou favorecia aos interesses senhoriais foram frequentes, obrigando-nos a remodelarmos nosso olhar. Para perceber a crítica machadiana aos interesses senhoriais nas fontes administrativas, precisamos, em alguns momentos, ler os processos à contrapelo. É necessário ressaltar a impossibilidade de assumir uma total apatia do Buxo do Cosme Velho. Não se trata aqui de retomar a interpretação segundo a

11. Marcelo Badaró Mattos, María Verónica Secreto e Rafael de Bivar Marquese discorrem sobre as diferentes apropriações do conceito de agência em Edward Palmer Thompson no Brasil. Eles demonstram como algumas das utilizações desta categoria se afastaram dos elementos estruturais e sistêmicos importantes para este autor.Ver respectivamente: Marcelo Badaró Mattos, E. P. Thompson e a tradição de crítica ativa do materialismo histórico (Rio de Janeiro: Editora da UFRJ, 2012); María Verónica Secreto, "Novas perspectivas na história da escravidão", Tempo 22.41 (2016): 442-450; Rafael de Bivar Marquese, "As desventuras de um conceito: capitalismo histórico e a historiografia sobre a escravidão brasileira”, Revista de História 169 (2013): 223-253. 
qual ele não reagiria às mazelas de seu tempo. Concordamos que este indivíduo fez a sua história e conscientemente criticou perspectivas senhoriais; porém, fez isso diante de condicionamentos e limites existentes. Propomos pensar o que foi possível fazer do que a sociedade fez dele, diante da realidade institucional e das hierarquias de seu tempo. Trata-se de ter em mente que ele fez a sua história diante de relações sociais e limites pré-existentes. Para isso, precisamos destacar as diferentes facetas deste escritor em relação a questão agrária oitocentista. Iniciaremos abordando seus textos literários; apresentaremos alguns deboches deste intelectual com relação à forma dos potentados rurais imaginarem a propriedade da terra. Em seguida, revelaremos alguns casos nos quais ele atuou enquanto chefe da Diretoria da Agricultura e manifestou uma faceta favorável aos pequenos proprietários. Por fim, trataremos de alguns dos processos nos quais ele se aproximou das compreensões dos potentados rurais sobre a propriedade.

Em nossa pesquisa, lidamos com várias outras pendengas fundiárias e administrativas em que Machado deixou sua assinatura; porém, escolhemos expor aqui os casos mais representativos da diversidade de facetas adotadas por ele em sua trajetória. Assim, estaremos também evidenciando as diversas cores com as quais ele se apropriou da palheta proprietária e como, longe de uma perspectiva unitária e coerente, ele produziu olhares diferentes sobre a questão fundiária, dependendo das relações sociais e institucionais com as quais interagiu.

\section{O humor Machadiano e a perspectiva senhorial}

Machado de Assis debochou em sua literatura do modo dos potentados rurais oitocentistas conceberem a propriedade e se posicionarem nos conflitos fundiários. ${ }^{12}$ O humor para com esses elementos da realidade apareceu em, pelo menos, dois escritos literários deste autor: no conto $\mathrm{Na}$ arca e no romance Memórias Póstumas de Brás Cubas. Nos dois casos, ele embutiu as suas galhofas no discurso de personagens ou narradores.

$\mathrm{Na}$ década de 1870 , a literatura machadiana foi criticada por literatos naturalistas. ${ }^{13}$ Eles associavam Machado de Assis ao romantismo. Alguns desses críticos, dentre eles Silvio Romero, questionavam esta escola literária, propondo em substituição uma arte respaldada no cientificismo determinista. Para eles, era necessária uma preocupação em retratar a realidade ausente no romantismo. Nessa década, Machado de Assis rompeu gradualmente com a escola romântica, mas também não se adequou ao realismo ou ao naturalismo. Em resposta aos seus críticos, adotou narradores em terceira pessoa pouco confiáveis e outros personagens com perspectivas restritas sobre a realidade. ${ }^{14}$ Estas figuras criadas por Machado muitas

12. Pedro Parga Rodrigues, "A experimentação literária de Machado de Assis e o tema da propriedade da terra no XIX”, Revista Cantareira 28 (2018): 101-112.

13. Ramos 105-216.

14. Marcelo Pen Pereira, "Estratégias do Falso. Realidade possível em Henry James e Machado de 
vezes eram de origem senhorial e seus discursos, se lidos à contrapelo, traziam implicitamente um deboche com relação à visão de mundo desses atores sociais que representavam.

Ao longo da década de 1870, Machado de Assis realizou um processo de experimentação literária, partindo de seus contos e culminando no romance Memórias Póstumas de Brás Cubas. ${ }^{15} \mathrm{O}$ conto Na Arca foi originalmente publicado em 1878 no jornal O Cruzeiro e foi parte desta testagem de estilos literários. ${ }^{16}$ Alguns deboches existentes nele, com relação à questão agrária, foram recuperados em 1881 no romance previamente citado. Um ano mais tarde, o conto foi incluído na coletânea Papeis Avulsos com algumas modificações, como aquela em que o autor removeu a introdução do conto, na qual debochava da retórica cientificista de seu tempo através de uma apresentação realizada pelo narrador-personagem Eleazar.

Uma das críticas implícitas em Na Arca guarda relação com o entendimento senhorial, segundo o qual o direito de propriedade seria exclusividade desta classe; algo que aparece em diferentes fontes oitocentistas, nas quais potentados locais demonstram esta percepção, propondo a si mesmos como monopolizadores das prerrogativas proprietárias. Em meados do XIX, por exemplo, Luís Peixoto de Lacerda Werneck, um membro da família senhorial do sul fluminense, escreveu: "A classe agrícola, que não pode despender os capitais necessários para haver um terreno próprio, vive agregada aos grandes possuidores do solo, e por um contrato a título precário, isto é, pode ser despejada, quando bem convier ao dono da terra". ${ }^{17} \mathrm{Na}$ percepção deste potentado rural, não havia pequenos posseiros, tampouco outros homens pobres livres com direitos à terra; ao contrário, somente aqueles com capitais teriam prerrogativas sobre o solo, restando aos outros viverem de favor, como agregados. Ideias semelhantes também foram defendidas pelo Barão de Itamaracá no parlamento, quando afirmou: "Os terrenos do interior são todos de fazendeiros proprietários, os pequenos lavradores apenas têm terras concedida pelos proprietários". ${ }^{18}$ Mais uma vez, um membro da classe senhorial apresentou a propriedade da terra como monopólio dos seus similares. Esta era uma postura comum entre fazendeiros.

Assis" (Tese de doutorado em Teoria Literária e Literatura Comparada, Universidade de São Paulo, 2007) 184.

15. Janaína Tatim e Antônio Marcos V. Sanseverino, "A experimentação de Machado de Assis e a sedimentação dos gêneros literários", Todas as Musas 4.2 (2013): 183-199; John Gledson e Lúcia Granja, coords., Notas Semanais (Campinas: Editora da Unicamp, 2008) 21.

16. Rodrigues, "A experimentação literária” 101-112.

17. Luís Peixoto de Lacerda Werneck, Idéas sobre colonisação precedidas de uma succinta exposição dos princípios geraes que regem a população (Rio de Janeiro: Eduardo e Henrique Laemmert, 1855) 36.

18. Annaes do Parlamento Brazileiro (Rio de Janeiro: Typoggraphia de Hippolyto J. Pinto, 1876) 740; apud Cláudio Lopes Maia, "Os donos da terra: a disputa pela propriedade e pelo destino da fronteira - a luta dos posseiros em Trombas e Formoso 1950-1960" (Tese de doutorado em História, Universidade Federal de Goiás, 2008) 93. 
De modo que Machado de Assis embutiu críticas a essa percepção nos discursos das personagens da paródia à Bíblia Na Arca. Nela, a família de Noé chega à terra prometida após o dilúvio; porém, em nenhum momento deixam a embarcação. Então, o único cenário deste conto é a arca construída pelo patriarca para salvar a vida na terra. Assim, todos esperam as águas da inundação reduzirem o seu volume para aportarem em uma montanha da qual podem observar apenas o topo. Entretanto, isto não impede dois filhos do patriarca brigarem pelos limites territoriais como se fossem os únicos a terem direitos sobre os territórios; apresentando um aos outros como invasor ou como quem esbulha posse alheia. Os dois irmãos apenas reconhecem os seus próprios direitos, negando totalmente quaisquer prerrogativas de seus interlocutores, disputam os limites de uma terra sobre a qual não possuem conhecimento das dimensões precisas — pois enxergam somente o "cabeço de uma montanha"19 — e conversam sobre como serão suas vidas nas terras avistadas, usando sempre verbos no futuro.

O deboche para com a perspectiva senhorial também está presente quando Jafé afirma aos seus parentes: "Porquanto seremos únicos na terra, e toda a terra será nossa". ${ }^{20}$ Este descendente de Noé se preocupa em afirmar que serão os únicos habitantes do território e, ao mesmo tempo, a exclusividade dos poderes de seus familiares sobre o solo. Desta forma, seus discursos trazem implicitamente uma perspectiva senhorial acerca da propriedade territorial. $\mathrm{O}$ fato de as personagens do conto tratarem sobre uma terra desconhecida acrescenta comicidade a estas noções compartilhadas por elas e pelos potentados rurais oitocentistas.

Ao teorizar sobre o humor, Jacques Le Goff propõe: "Conte-me se você ri, como você ri, por que você ri, de quem você ri, do que você ri, com quem você ri e contra quem você ri, e eu te direi quem você é". ${ }^{21}$ Então, ainda que a comédia sempre possua um alvo - podendo ser um discurso, um grupo social, uma sexualidade, preconceitos etc. - a escolha daqueles contra quem o enunciado humorístico se destina tem muito a dizer sobre o seu emissor e seus valores inconscientes. Sendo a comédia uma atividade social, sempre traz consigo um posicionamento nas arenas políticas existentes.

Desta forma, podemos ver o tom crítico do Machado de Assis; pois representou com comicidade as noções de propriedade senhorial. As personagens do conto disputam os limites de uma terra desconhecida. Mesmo assim, apresentam-se como detentoras exclusivas do solo e representam seus interlocutores como invasores dessas terras. Eles percebem a si próprios como detentores exclusivos desses quinhões virtuais. Neste sentido, são bastante parecidos com o fazendeiro fluminense Luís Peixoto de Lacerda Werneck, o Barão de Itamaracá e inúmeros outros potentados ruais oitocentistas; mostrando como os conflitos fundiários nos quais

19. Machado de Assis, "Três Capítulos inéditos do Gênesis", O Cruzeiro (Rio de Janeiro) 14 de maio de 1878: 1 .

20. Assis 1 .

21. Jacques Le Goff, "Une enquête sur le rire”, Annales. Histoire, Sciences Sociales 52.3 (1997): 449. 
os senhores de escravos se envolviam e suas perspectivas eram os alvos centrais do humor contido no referido conto machadiano.

Uma segunda crítica dissimulada por nosso autor em seus escritos literários se dirige à noção patriarcal sobre a propriedade compartilhada por muitos potentados rurais do Império. Eles percebiam a fazenda como espaço exclusivo de mando dos chefes familiares, negando a possibilidade de o Estado intervir no cotidiano destas terras - seja para regular as relações de trabalho, para demarcar os limites territoriais delas, averiguar os títulos imobiliários ou taxá-las. José Murilo de Carvalho já apontou a recusa do que ele chamou de "elite econômica" com relação à possibilidade de se instituir um imposto territorial. ${ }^{22}$ Estes agentes sociais argumentavam direito absoluto de propriedade em contraposição a esta taxação. Também houve reações senhoriais contra a possibilidade da Lei do Ventre Livre garantir direitos aos cativos de comprarem suas alforrias. ${ }^{23}$ Em relatórios ministeriais, os titulares da pasta da agricultura defendiam uma moderação na proposta de regularização fundiária contida em alguns dispositivos da Lei de Terras de $1850,{ }^{24}$ recusando a possibilidade de medir e demarcar as propriedades sem o consentimento dos proprietários rurais.

Machado de Assis também debocha desta noção patriarcal de propriedade através dos discursos do narrador-personagem do romance Memórias Póstumas de Brás Cubas. Neste livro, um membro da família senhorial falecido, Brás Cubas, apresenta aos leitores suas memórias de vida. Em um trecho, este narrador (nada confiável) descreve a residência onde encontrava com a amante, afirmando: “[...] o mundo terminaria à porta; - dali para dentro era o infinito, um mundo eterno, superior, excepcional, nosso, somente nosso, sem leis, sem instituições [...]”. Estes termos foram, para Chalhoub, a prova de que o narrador apresentava noções de propriedade nos critérios sonhados pelos membros da classe senhorial. ${ }^{25} \mathrm{~A}$ personagem, assim como os potentados oitocentistas, imaginava seus domínios como sendo imunes aos desígnios estatais. Em outras palavras, Machado dissimulou nos discursos de Brás Cubas as noções de propriedade típicas da classe social representada neste narrador-personagem.

Em definitivo, Machado criticou os conflitos fundiários do Império; pois tanto o conto quanto o romance em questão são evidências de que o Bruxo do Cosme Velho debochou das perspectivas senhoriais sobre a propriedade. Nestes temos, ele exibiu uma faceta crítica quanto às compreensões dos potentados acerca dos direitos agrários e, discretamente, nos discursos do narrador do romance e das

22. José Murilo de Carvalho, A construção da ordem: a elite política imperial. Teatro das sombras: a política imperial (Rio de Janeiro: Civilização Brasileira, 2003) 57.

23. Joseli Maria Nunes Mendonça, Entre a mão e os anéis. A lei dos sexagenários e os caminhos da abolição no Brasil (Campinas: Editora da Unicamp, 1999); Eduardo Spiller Pena, Pajens da casa imperial: jurisconsultos, escravidão e a lei de 1871 (Campinas: Editora da Unicamp, 2001).

24. Pedro Parga Rodrigues, "A Lei de Terras de 1850 e os Relatórios do Ministério da Agricultura entre 1873-1889”, Revista Maracanan 17 (2017): 103-117, doi: 10.12957/revmar.2017.27435.

25. Chalhoub 75. 
personagens do conto, criticou a compreensão de agentes sociais sobre a questão fundiária. Desta forma, também fez frente às preocupações com a representação do real presente no naturalismo, pois apenas ofereceu aos seus leitores as perspectivas limitadas pelo ângulo do qual as personagens olhavam o mundo rural. Não se interessou em retratar a realidade por completo. ${ }^{26}$ Ao contrário, usou as perspectivas de pessoas de seu tempo para criar as retóricas de suas personagens.

\section{Dois casos no Espírito Santo e a faceta crítica de Machado de Assis}

Neste apartado, trataremos a faceta mais crítica de Machado de Assis; demonstrada em, pelo menos, dois processos de solicitação de terras espírito-santenses. A primeira tramitação iniciou em 19 de julho de 1876 quando a fazendeira, Luísa Amália Ferreira, requereu por compra um terreno confinante com a sua fazenda. ${ }^{27}$ Ela anunciava ser "senhora e possuidora de um prazo de terras com cultura de café" e afirmava possuir "escravatura suficiente" para cultivar as terras pretendidas. ${ }^{28}$ Ademais, deixava claro possuir as terras vizinhas à solicitada, bem como ter capacidade de cultivar todas as áreas desejadas. Assim, sua estratégia argumentativa era condizente com as exigências da Lei de Terras de 1850, norma que favorecia os solicitantes que possuíssem os terrenos contíguos aos demandados. Sua argumentação também acompanhava estratégias comuns entre outros peticionários.

Antes de passar pelas mãos do Bruxo do CosmeVelho, o processo recebeu um parecer do juiz comissário José Alves da Cunha Bastos, afirmando: "sem que ela proceda a medição das que possuí, não se sabe nem se pode discriminar as terras

26. Não estamos criticando aqui o escritor Machado de Assis. Não ter se interessado em retratar a realidade não é um descuido, mas, sim, uma proposta artística. A literatura, diferente da história, não precisa pretender quaisquer verossimilhanças. Não existe uma insuficiência no escrito machadiano por não desejar este fim. Não entraremos aqui em um debate sobre a questão da subjetividade e/ou objetividade no conhecimento histórico. Basta dizer que a pretensão empirista de alguns historiadores do século XIX já foi bastante superada. Machado, como bem demonstrou Richard Mislkolci, debochava das pretensões cientificistas e objetivistas de alguns intelectuais de seu tempo. Este pesquisador bem demonstrou como este escritor discordou das pretensões de verdade absoluta e do didatismo de autores naturalistas. Roger Chartier evidenciou como toda fonte, literária ou não, traz consigo representações do real. Todos os documentos trazem uma subjetividade relacionada ao contexto no qual foram elaboradas. Sendo assim, a pretensão, dos autores naturalistas, de representar o real, com base nas ideias deterministas, não consegue fazer as obras literárias retratar o real. Elas continuavam trazendo consigo representações. Como afirma Carlo Ginzburg, "escavando os meandros dos textos, contra as intenções de quem os produziu, podemos fazer emergir vozes incontroladas".Ver Richard Miskolci, "Machado de Assis, o outsider estabelecido", Sociologias 8.15 (2006): 352-377; Roger Chartier, A história cultural: entre práticas e representações (Lisboa: Difel, 1990); Roger Chartier, Cultura escrita, literatura e história (Porto Alegre: Artmed, 2001); Carlo Ginzburg, O fio e os rastros: verdadeiro, falso, fictício (São Paulo: Companhia das Letras, 2007) 11.

27. Luísa Amália Ferreira, "Solicitação de concessão de terras devolutas no Espírito Santo", Espírito Santo / Rio de Janeiro, 1876-1877. FCRB, Rio de Janeiro, Coleção Machado de Assis, Processos.

28. Ferreira, "Solicitação de concessão" 1. 
devolutas com as particulares; tanto mais que as escrituras de compra das terras com os limites que dão, abrange todo terreno a encontrar com outros moradores". ${ }^{29}$

No dia 7 de maio de 1877, Machado de Assis, exercendo chefia na Diretoria da Agricultura, concordou com este parecer, afirmando: "Ao meu ver a informação do juiz comissário é bastante para propor a V. Ex. o indeferimento desta pretensão" ${ }^{30}$ Embora a autora possuísse requisitos estabelecidos pela legislação, estes funcionários negaram o seu pedido, argumentando não terem sido as terras adequadamente regularizadas. As dificuldades de precisar os limites fundiários causavam conflitos naquela localidade. ${ }^{31}$ Os territórios demandados por ela poderiam ser ocupados por outros moradores. A fazendeira poderia estar comprando do Estado exatamente para expandir seus domínios nas brechas legais. Isto era uma prática recorrente entre os potentados no vale-tudo fundiário oitocentista. Desta forma, os funcionários públicos colocaram freios nas pretensões de Luísa Amália Ferreira.

O segundo processo no qual Machado de Assis se posicionou de forma crítica aos interesses senhoriais foi motivado pela requisição de José Theodoro de Andrade de uma "sesmaria de terras devolutas no Rio doce, à margem do Ribeirão Sobreiro, afluente do rio Santa Joana”. ${ }^{32}$ Em 26 de julho de 1877, o inspetor Alfredo Rodrigues Fernandes Chaves avaliou esta petição, afirmando "não haver inconveniente em conceder a graça impetrada" e argumentando que o requerente dispunha "de forças para cultivar as terras". ${ }^{33}$ Ainda anunciou que "são mais aproveitadas as terras distribuídas por pequenos agricultores, já porque assim procedendo-se, evitam-se possuidores de extensos terrenos, sempre propensos a cometerem abusos contra os pequenos agricultores e seus vizinhos". ${ }^{34}$ No dia 2 de agosto de 1877, o processo chegaria à mesa de Machado de Assis e ele aprovou a solicitação, afirmando o seguinte: “A inspetoria é favorável à pretensão, já porque o peticionário tem forças para cultivar as terras, já porque estas não embaraçam o desenvolvimento da colônia Santa Leopoldina. Outrossim, entende que o preço deve ser de 1 real a braça quadrada; a concessão não convém que excede de meia légua. São mais aproveitadas as terras distribuídas a pequenos agricultores. De inteiro acordo". ${ }^{35}$

Ambos os funcionários revelaram uma valorização do pequeno agricultor, em detrimento do latifúndio: Alfredo Chaves evidenciou sua preocupação com o fato de os grandes proprietários tenderem expandir suas terras sobre as posses

29. Ferreira, "Solicitação de concessão" 9.

30. Ferreira, "Solicitação de concessão" 11 .

31. Solange Faria Prado, "O poder e a luta pela propriedade da terra no Vale do rio Iconha / Piúma: o caso Thomaz Dutton Junior (1870-1906)" (Tese de doutorado em História, Universidade Federal do Espírito Santo, 2018) 66.

32. José Theodoro de Andrade, "Solicitação de concessão de terras devolutas no Espírito Santo", Espírito Santo / Rio de Janeiro, 1876-1877. FCRB, Rio de Janeiro, Coleção Machado de Assis, Processos.

33. Andrade, "Solicitação de concessão" 2-3.

34. Andrade, "Solicitação de concessão" 2-3.

35. Andrade, "Solicitação de concessão" 1. 
de moradores confinantes e Machado de Assis, de forma mais discreta, sendo mais econômico com as palavras, concordou com o parecer da inspetoria. Esses posicionamentos guardavam relações com a estrutura agrária espírito-santense; pois, nesta província, predominaram propriedades menores do que na cafeicultura do Sul fluminense. ${ }^{36}$ Ainda assim, Alfredo Chaves e Machado, de alguma forma, posicionaram-se nestes casos criticamente às práticas de potentados invadirem terras alheias. A ausência de uma discriminação dos limites fundiários garantia a continuidade dos conflitos agrários, das grilagens etc. Ao seu modo, e dentro das possibilidades institucionais existentes, o Bruxo do Cosme Velho revelou nestes casos a sua faceta contrária aos abusos senhoriais.

Estes e outros processos passavam por um trâmite bastante similar, porque eram iniciados nas diversas Presidências das províncias e, antes de chegar na Diretoria da Agricultura, recebiam pareceres de autoridades locais: dos presidentes provinciais (escolhidos pelo governo central, mas fortemente articulados com as relações de forças locais), dos juízes comissários, bem como dos Inspetores de Terras Públicas e Colonização. Em raras ocasiões, eram adensados com as opiniões dos legislativos municipais, diretores de estradas de ferro ou outros agentes. Então, quando chegavam na Diretoria, um primeiro oficial se manifestava sobre os casos, corriqueiramente retomando um dos posicionamentos emitidos na província de origem; mas, em casos de divergência entre autoridades locais, o oficial dava mais voz a um dos discursos emitidos anteriormente. Por fim, o caso chegava às mãos do chefe de seção. Foram raros os processos nos quais esse percurso não foi respeitado; já que, sempre que possível, Machado de Assis tendeu a ratificar os pareceres de seus colegas ou a ser lacunar, deixando de manifestar suas perspectivas. Em grande parte dos casos, ele simplesmente adicionou o termo "concordo"; mas, em alguns momentos, esse chefe de seção discordou dos documentos emitidos por outras repartições.

No exercício de suas atividades enquanto funcionário público, ele não possuía uma autonomia irrestrita; mas, ao contrário, precisava lidar com toda uma cadeia de pareceres submersos nas relações de prestígios e poder das diferentes províncias. Após ler esses documentos, devia emitir uma decisão que dialogasse com as expectativas de outros interlocutores: presidentes do conselho de ministros, ministros, partes envolvidas no caso, cidadãos interessados nas posturas ministeriais e outras forças políticas. Em outras palavras: ele exercia sua agência dentro de limites colocados pelas relações nas quais atuava.

Os casos em tela se relacionam com a dinâmica agrária espírito-santense. $\mathrm{Na}$ quele período, a força dos agentes ligados aos núcleos coloniais foi uma das características das relações de força dessa província. ${ }^{37} \mathrm{~A}$ produção cafeeira capixaba era costumeiramente realizada em áreas menores do que no território fluminense. As relações de poder locais e os pareceres dos funcionários antecedentes foram fatores importantes nas decisões de Machado de Assis. A forma elástica com que

36. Gilda Rocha, Imigração estrangeira no Espírito Santo, 1847-1896 (Vitória: [s.n.], 2000) 53-34.

37. Prado 66. 
a fazendeira Luísa Amália Ferreira lidava com o seu território, possivelmente, se chocava com as preocupações dos diretores de núcleos coloniais com a delimitação dos domínios. Isto pode ter sido um fator motivador do indeferimento, pois Alfredo Chaves era um funcionário bastante ligado aos interesses dos diretores destes núcleos. Seu nome serviu, inclusive, para batizar um desses empreendimentos. O posicionamento desse inspetor sobre a preferência por pequenos proprietários era possibilitado também por causa das dinâmicas agrárias daquela província, nas quais esses núcleos e a pequena propriedade eram marcas.

Machado, embora estivesse se pronunciando sobre um caso do Espírito Santo, escrevia seu parecer sob os olhares da Corte e no exercício de um cargo ministerial. Talvez isso ajude a explicar o fato dele ter sido mais comedido com as palavras. Ele referendou de forma lacunar a decisão proveniente dos pareceres locais. É possível assumir, portanto, um tom crítico nesta decisão, mas imerso nas circunstâncias do exercício da sua função. Porém, esta não foi a única aproximação desta personagem com a questão agrária oitocentista, assim que veremos agora os posicionamentos machadianos mais moderados e/ou conservadores.

\section{O prazo das medições de demarcações e a faceta "acomodada" machadiana}

Em 1876, José Manoel Felizardo e sua companheira solicitaram adiamento da data limite para demarcar domínios comprados anteriormente do Estado ${ }^{38}$, pois a Lei de Terras de 1850 estabelecia um prazo para realizar essas formalidades sob pena dos compradores perderem seus direitos territoriais. As terras dos autores do processo estavam localizadas na província do Rio Grande do Sul, próximo ao rio Uruguai. Em dezembro de 1877, o processo foi analisado pelo chefe da Segunda Seção da Diretoria de Agricultura, Machado de Assis: "Parece-me que a prorrogação pode ser concedida. Convém, entretanto, ouvir a Inspetoria Geral". 39

Para o chefe da segunda seção da Diretoria, o dilatamento do prazo de medição deveria ser deferido; mas ainda assim, ele buscou uma segunda opinião da Inspetoria. José Diniz Villas-Boas, na qualidade de oficial da Diretoria, comunicou, no dia 20 de dezembro de 1877, o posicionamento da outra repartição: "informa a Inspetoria Geral de Terras e Colonização que não devessem atender José Manoel Felizardo e Co. na prorrogação". ${ }^{40} \mathrm{O}$ posicionamento que a Inspetoria apresentou foi muito distinto daquele anunciado anteriormente pelo Bruxo do Cosme Velho; já que ele defendera o deferimento da demanda e o inspetor pleiteou o indeferimento. Machado, entretanto, pareceu não concordar com a proposta da outra

38. José Manoel Felizardo, "Requerimento de Durval e Pereira e à representação da assembleia provincial contra a concessão de 10 léguas em quadra, hoje reduzida a 4 léguas quadradas", Rio Grande do Sul / Rio de Janeiro, 1875-1877. AN, Rio de Janeiro, Seção de Guarda Codes, Fundo GIFI, Notação 5b-256.

39. Felizardo, "Requerimento de Durval" 16-17.

40. Felizardo, "Requerimento de Durval” 18. 
repartição, posto que no dia seguinte subscreveu: "Sobre a pretensão de Felizardo e C ${ }^{a}$. S Ex. se impera resolver". ${ }^{41}$ Mesmo aceitando a decisão da inspetoria sobre outra questão suscitada naquele processo, deixou em aberto a solução relacionada com a ampliação do prazo de medição. Sem discordar diretamente de seus interlocutores no outro órgão, ele informou que a questão ainda precisaria ser resolvida pelo ministro. Discordava gentilmente, assim, da outra agência.

Na maioria dos casos considerados pela Diretoria - encontrados nos acervos do Arquivo Nacional e da Fundação Casa de Rui Barbosa - o chefe de seção, Machado de Assis, deu um desfecho para o requerimento; de modo que, geralmente, eles seguiam para o ministro com uma decisão formada. Este caso foi excepcional neste aspecto. Desta forma, o Bruxo do CosmeVelho indicou concordar com o deferimento da ampliação do prazo de medição e demarcação das terras.

Ele ainda se manifestou favoravelmente a outras autorizações de prorrogação dessas datas em outros processos similares: em 1887, chegava na Diretoria de Agricultura o processo de autoria de Francisco José Rodrigues de Souza; no qual demandava alargamento do período destinado à medição de um terreno concedido, para ele, em 1870, nas beiras do rio Purus. Tal concessão caíra em comisso por não ter sido medida em tempo. De acordo com o parecer da Inspetoria, "Tendo o suplicante pedido as terras em virtude da pena de comisso em que incorreu, é de parecer que, só por meio da nova concessão, poderá obtê-las o que julga de justiça". ${ }^{42}$ No dia 16 de junho de 1888, Machado apenas subscreveu "Concordo"; aderindo ao posicionamento desta repartição e ao de seu colega, João Capistrano do Amaral.

Utilizavam, assim, as brechas da legislação para assegurar a manutenção do exercício dos direitos de propriedade do requerente, escapando da penalidade de comisso estabelecida na legislação para o descumprimento do prazo de medição. $\mathrm{O}$ Decreto 5655 de 3 de junho de 1874 estabelecia um intervalo de seis meses para realização desse ato. O solicitante desejava uma ampliação do tempo de demarcação 18 anos depois de ter adquirido as mesmas. A solução dos agentes da Diretoria, com a qual Machado concordou, foi realizar uma nova alienação das mesmas áreas para aqueles que haviam deixado a data limite passar. Apenas informaram que o tamanho do território vendido não poderia ser o mesmo do anterior, pois a Circular de 5 de novembro de 1887 definia que a área máxima possível de ser concedida por venda era de 100 hectares. Desta forma, por um lado, abriam margens para a ampliação do prazo e, de outro, imputavam uma perda ao requerente, educando-o para realizar suas obrigações no período previsto na legislação; negociavam com os anseios senhoriais, operando segundo uma determinada "economia do poder de castigar". 43

41. Felizardo, "Requerimento de Durval" 18.

42. Francisco José Rodrigues de Souza, "Requerimento para demarcação de lote", Manaus, 1877. AN, Rio de Janeiro, Seção de Guarda Codes, Fundo GIFI, Notação 5b-256.

43. Este termo é utilizado por Michel Foucault. O autor apresenta uma transformação na "economia do poder de castigar" da França do século XVIII, deixando entrever que, tendo o poder uma natureza relacional, as autoridades não podem punir todos os crimes rigidamente, mas, ao 
Em 1888, os Majores Manoel Gomes Linhares e José Domingues Fraga, moradores do município de Carangola, em Minas Gerais, requeriam novo prazo para realizar os procedimentos necessários para legitimar os seus domínios. ${ }^{44} \mathrm{O}$ limite temporal destinado à medição já havia sido prorrogado em 1884. Por isso, pediam uma decisão "renovando a concessão que já lhes foi feita, confirmando-a, ou, meramente lhes concedendo os terrenos pedidos, onde os suplicantes têm morada habitual, trabalho efetivo e grandes benfeitorias, apropriadas à criação". ${ }^{45}$

Sobre esta demanda, tanto o inspetor geral Francisco Barros e Accioli de Vasconcelos, quanto Machado de Assis, concordavam que a terra poderia ser concedida novamente, mas com o seu tamanho reduzido de acordo com o disposto na Circular de 1887. Mais uma vez, na solicitação do Cônego Simão de Azevedo Campos, envolvendo terras do extinto aldeamento indígena de Escada em Pernambuco, era solicitada "ou a legitimação de uns terrenos [...] dos quais se diz senhor e possuidor há mais de 20 anos e que deixara de legitimar no prazo marcado - ou a venda por preço razoável na forma da lei de 18 de setembro de 1850". ${ }^{46}$

O funcionário da Diretoria da Agricultura José Diniz Villas Boas, em parecer datado de 19 de janeiro de 1877, apresentou o posicionamento previamente submetido pelo Conselheiro Procurador da Coroa, o qual havia informado: "que a legitimação das terras pretendidas pelo vigário de Escada, não pode realizar-se [...]; $2^{\circ}$ que bem reclamou a Câmara Municipal contra a apropriação das mesmas terras [...] por sua natureza inalienável". ${ }^{47}$

Depois de tramitar por diversos órgãos, em fevereiro de 1878, Diniz apresentou novo parecer; agora mencionando o posicionamento do Procurador Fiscal da Tesouraria da Fazenda, o qual afirmara: "Nos termos do aviso do ministério da fazenda de 18 de novembro de 1877 , poderá ser atendido o suplicante [...], concedendo-se lhe por aforamento os terrenos requeridos" ${ }^{48}$ Não sendo possível legitimar a terra caída em comisso, nem tampouco vendê-la novamente ao requerente, agentes públicos propunham abrir mais uma brecha para preservar o solicitante na posse dos terrenos: aforá-las. Novamente, Machado de Assis se limitou a subscrever "De acordo". 49

Nos casos de solicitação de mais prazos para a medição e demarcação encontrados, Machado de Assis acabou operando no sentido de assegurar a manutenção das possessões dos requerentes, mesmo diante da não ocorrência da medição no prazo

contrário, precisam atenuar a rigidez de algumas penas, de forma a assegurar o exercício do próprio poder.Ver Michel Foucault, Microfísica do poder (Rio de Janeiro: Graal, 2013) 63-87.

44. Manoel Gomes Linhares,"Solicitação de regularização de concessão de terras devolutas em Minas Gerais", Minas Gerais / Rio de Janeiro, 1888. FCRB, Coleção Machado de Assis, Processos.

45. Linhares, "Solicitação de regularização" 4.

46. Cônego Simão de Azevedo Campos, "Solicitação de novo prazo para legitimação de posse de terras em Pernambuco". Pernambuco / Rio de Janeiro, 1888. FCRB, Coleção Machado de Assis, Processos.

47. Campos, "Solicitação de novo" 2.

48. Campos, "Solicitação de novo" 5.

49. Campos, "Solicitação de novo" 3. 
previsto legalmente. Ele não foi o único membro da Diretoria a defender o deferimento destas requisições: No primeiro caso narrado até houve discordâncias discretas sobre o assunto; porém, nos seguintes, os funcionários da Diretoria pareceram atuar em sintonia no sentido de atenuar as penalidades previstas, negociando com os potentados abertura de brechas na legislação, para assegurar os domínios daqueles que perdiam os prazos de demarcação, inclusive, até por uma margem de 18 anos.

Aquelas decisões foram tomadas pelos funcionários da Diretoria da Agricultura no exercício de uma autoridade mediada pelas relações internas desta própria repartição; seus discursos incorporam as expectativas dos interlocutores, bem como as relações sociais e institucionais com as quais interagiam. Os posicionamentos manifestados nesses processos eram condicionados pela interlocução com as hierarquias instituídas naquela sociedade e no MACOP. A hegemonia dos discursos senhoriais do Sul fluminense e os limites colocados pelas relações institucionais também eram partes integrantes dessas decisões.

Não era possível descartar completamente as noções de propriedade destes potentados rurais ao tomar decisões ministeriais, pois suas perspectivas possuíam grande capilaridade naquele contexto. Os funcionários traziam para as repartições públicas valores conscientes e inconscientes forjados nas suas experiências naquela sociedade, na qual circulavam diferentes retóricas com impactos diferentes no senso comum, ${ }^{.0}$ embora viessem de diferentes províncias, viviam e exerciam suas funções no Rio de Janeiro. Segundo Salles, "a Corte desempenhou como polo de formação, através de um processo de atração e aglutinação de intelectuais oriundos de configurações regionais distintas", ${ }^{51}$

Nestas contingências, Machado de Assis demonstrou uma faceta mais acomodada; pois acabou corroborando com os constantes adiamentos dos prazos de medição e demarcação das terras descritos por Carvalho. ${ }^{52}$ Este autor menciona como os prazos estabelecidos na legislação agrária para essas formalidades foram constantemente adiados.

\section{Conclusão}

Em primeiro lugar, podemos bater mais uma vez na tecla segundo a qual a interpretação do veto dos Barões, proposta por José Murilo de Carvalho, é insuficiente para

50. Entende-se aqui senso comum na acepção de Gramsci. Para o autor, o senso comum traz consigo projetos e discursos produzidos pelos intelectuais de diferentes classes. Entretanto, os grupos hegemônicos conseguem um predomínio das ideias dos grupos hegemônicos, de tal forma que seus projetos passam a ser aceitos como universais e naturais por grande parte da sociedade. Como consequência, muitas vezes, funcionários encarregados da administração pública acabam favorecendo estes interesses no exercício de suas atividades independentemente de suas origens. Ver Antonio Gramsci, Os intelectuais e a organização da cultura (Rio de Janeiro: Civilização Brasileira, 1982).

51. Ricardo Henrique Salles, "O Império do Brasil no contexto do século XIX. Escravidão nacional, classe senhorial e intelectuais na formação do Estado”, Almanack 4 (2012): 44, doi: 10.1590/2236-463320120401.

52. Carvalho 57 . 
entendermos a aplicação das legislações agrárias oitocentistas. ${ }^{53}$ Este autor defendeu que a Lei de Terras teria sido promulgada pelos burocratas, defendendo uma regularização fundiária; mas, em sua interpretação, esta norma não teria sido aplicada por causa das resistências dos potentados rurais. Na perspectiva dele, os barões teriam vetado na prática a execução da norma. Ao falar dos constantes adiamentos dos prazos de medição, afirma que o governo era forçado postergá-los. Ao contrário do afirmado por este autor, os funcionários ministeriais cooperaram com a ampliação do período destinado para realizar tais formalidades; sendo assim, a dicotomia entre potentados e burocratas não é o suficiente para explicar os adiamentos das datas limites de medição ou a não-realização de uma regularização fundiária. Inúmeros trabalhos já caminharam no sentido de criticar a interpretação proposta por José Murilo de Carvalho: Márcia Maria Menendes Motta demonstrou não ser possível considerá-la totalmente sem efeito, pois foi interpretada e usada de formas diversas por diferentes agentes sociais. ${ }^{54}$ Ela defende a importância de interpretarmos esta norma tendo em vista os conflitos de cada localidade; Cristiano Luís Christillino revelou uma negociação entre a Coroa e parcela da elite sul-rio-grandense na aplicação destes dispositivos jurídicos. ${ }^{55}$ Para ele, a Coroa permitiu a esses potentados falsificarem propriedades, usando desta forma a Lei de Terras como barganha em troca de apoio para o projeto de centralização do Estado; Flávia Paula Darossi também caminha no mesmo sentido, ao evidenciar a negociação entre "cidadãos proprietários" de Santa Catarina e o governo imperial no processo de regularização fundiária de Lages, ${ }^{56}$ Márcio Antônio Both da Silva propõe estudar a norma pelo que ela de fato realizou, contrariando as narrativas segundo as quais a referida legislação seria letra morta, ${ }^{57}$ e Pedro Parga Rodrigues recorreu aos relatórios ministeriais utilizados como fontes por José Murilo de Carvalho, demonstrando que, embora os titulares da pasta reclamassem da inefetividade da Lei de Terras de 1850, contraindicavam uma aplicação rigorosa da norma. ${ }^{58}$

Aqui, apresentamos funcionários estatais criando brechas na legislação. Eles operavam com essa norma interagindo com as relações sociais e institucionais nas quais atuavam. Se pode notar, como as relações entre funcionários públicos e potentados rurais eram mais complexas do que a tese do veto dos barões poderia

\section{Carvalho 57.}

54. Márcia Maria Menendes Motta, Nas fronteiras do poder: conflito e direito à terra no Brasil do século XIX (Niterói: Arquivo Público do Estado do Rio de Janeiro, 1998).

55. Cristiano Luís Christillino, "Litígios ao sul do Império: a Lei de Terras e a consolidação política da Coroa no Rio Grande do Sul (1850-1880)" (Tese de doutorado em História, Universidade Federal Fluminense, 2010).

56. Flávia Paula Darossi, "A Lei de Terras em Santa Catarina e a política fundiária Imperial: a força do poder local pela Câmara Municipal de Lages e a Sociedade Lageana para Exportar Erva-Mate”, História, Histórias 6.12 (2018): 136-154, doi: 10.26512/hh.v6i12.19263.

57. Márcio Antônio Both da Silva, "Lei de Terras de 1850: lições sobre os efeitos e os resultados de não se condenar 'uma quinta parte da atual população agrícola", Revista Brasileira de História 35.70 (2015): 97-107, doi: 10.1590/1806-93472015v35n70014.

58. Rodrigues, “A Lei de Terras de 1850” 103-117. 
supor, pois os agentes da própria repartição encarregada de aplicar a Lei de 1850 dialogaram com os interesses senhoriais em alguns contextos.

Ademais, seus cargos não tinham estabilidade, pelo qual suas decisões não foram realizadas no vácuo; existia uma teia de relações institucionais e sociais com as quais interagiam. De maneira que, se não o fizeram por convicção, ao menos se acomodaram para manter seus empregos. Isto não significa que eles tenham se rendido totalmente aos desígnios de seus interlocutores; o fato é que atuaram no sentido de adiar os prazos de medição das terras, mas impuseram um ônus àqueles que perderam a data limite. Desta forma, adotaram um posicionamento dúbio.

Finalmente, restringindo-nos ao objetivo do artigo em tela, podemos concluir que a trajetória de Machado de Assis não deve ser narrada somente ressaltando sua faceta crítica aos interesses senhoriais, porque isto seria criar o que Bourdieu chamou de "ilusão biográfica", isto é, gerar uma narrativa que produz uma aparência de coerência em uma trajetória marcada por descontinuidades. ${ }^{59}$

Claramente, os posicionamentos do escritor oitocentista foram diferentes em cada contexto. Podemos recorrer a Marx, anunciando que ele fez a sua história, mas não nas circunstâncias desejadas; em alguns momentos, precisou dialogar com as contingências institucionais nas quais trabalhava, mas suas ações não eram totalmente determinadas por elas. Alguns agentes daquele momento perderam seus empregos por defenderem abolicionismos. Assim, Machado, de um lado, criticou o cativeiro discretamente em sua literatura e atuou em alguns processos administrativos de forma a favorecer os escravos; também debochou da realidade agrária oitocentista e dos valores de propriedade senhorial e, em alguns processos, contrariou os anseios dos potentados rurais. Entretanto, em outras circunstâncias, acabou corroborando com os interesses senhoriais. Ele foi um dos funcionários que operaram no sentido de favorecer os interesses senhoriais, postergando os prazos de medição e demarcação de terras.

\section{Fontes}

\section{Manuscritas}

Arquivo Nacional, Rio de Janeiro (AN)

Seção de Guarda Codes

Fundação Casa Rui Barbosa, Rio de Janeiro (FCRB)

Coleção Machado de Assis

\section{Impressas}

Annaes do Parlamento Brazileiro. Rio de Janeiro:Typoggraphia de Hippolyto J. Pinto, 1876 
Werneck, Luís Peixoto de Lacerda. Idéas sobre colonisação precedidas de uma succinta exposição dos princípios geraes que regem a população. Rio de Janeiro: Eduardo e Henrique Laemmert, 1855.

\section{Periódicos}

O Cruzeiro (Rio de Janeiro) 1878.

\section{Bibliografia}

Alonso, Angela. Flores, votos e balas. O movimento abolicionista brasileiro (1868-88). São Paulo: Companhia das Leras, 2015.

Bourdieu, Pierre. “A ilusão biográfica”. Usos e abusos da história oral. Coords. Janaína Amado e Marieta de Moraes Ferreira. Rio de Janeiro: Editora FGV, 2006.

Carvalho, José Murilo de. A construção da ordem: a elite política imperial. Teatro das sombras: a política imperial. Rio de Janeiro: Civilização Brasileira, 2003.

Chalhoub, Sidney. Machado de Assis, historiador. São Paulo: Companhia das Letras, 2003.

Chartier, Roger. A história cultural: entre práticas e representações. Lisboa: Difel, 1990. . Cultura escrita, literatura e história. Porto Alegre: Artmed, 2001.

Christillino, Cristiano Luís. "Litígios ao sul do Império: a Lei de Terras e a consolidação política da Coroa no Rio Grande do Sul (1850-1880)”. Tese de doutorado em História, Universidade Federal Fluminense, 2010.

Darossi, Flávia Paula. “A Lei de Terras em Santa Catarina e a política fundiária Imperial: a força do poder local pela Câmara Municipal de Lages e a Sociedade Lageana para Exportar Erva-Mate". História, Histórias 6.12 (2018): 136-154. Doi: 10.26512/hh.v6i12.19263.

Duarte, Eduardo de Assis. Machado de Assis afrodescendente. Belo Horizonte: Pallas, 2009.

. "A capoeira literária de Machado de Assis". Machado de Assis em Linha 2.3 (2009): 27-38.

Foucault, Michel. Microfísica do poder. Rio de Janeiro: Graal, 2013.

Ginzburg, Carlo. O fio e os rastros: verdadeiro, falso, fictício. São Paulo: Companhia das Letras, 2007.

Gledson, John. Por um novo Machado de Assis. Ensaios. São Paulo: Companhia das Letras, 2006.

Gledson, John e Lúcia Granja. Coords. Notas Semanais. Campinas: Editora da Unicamp, 2008.

Gramsci, Antonio. Os intelectuais e a organização da cultura. Rio de Janeiro: Civilização Brasileira, 1982.

Guimarães, Hélio de Seixas. Machado de Assis, o escritor que nos lê. As figuras machadianas através da crítica e das polêmicas. São Paulo: Editora Unesp, 2017.

"O Machado terra-a-terra de John Gledson". Novos Estudos - CEBRAP 77 
(2007): 261-271.

. Os leitores de Machado de Assis. O romance machadiano e o público de literatura no século 19. São Paulo: Nankin y Edusp, 2012.

Le Goff, Jacques. "Une enquête sur le rire”. Annales. Histoire, Sciences Sociales 52.3 (1997): 449-455.

Maia, Cláudio Lopes. "Os donos da terra: a disputa pela propriedade e pelo destino da fronteira - a luta dos posseiros em Trombas e Formoso 1950-1960" Tese de doutorado em História, Universidade Federal de Goiás, 2008.

Marquese, Rafael de Bivar. “As desventuras de um conceito: capitalismo histórico e a historiografia sobre a escravidão brasileira”. Revista de História 169 (2013): 223-253.

Mattos, Marcelo Badaró. E. P. Thompson e a tradição de crítica ativa do materialismo histórico. Rio de Janeiro: Editora da UFRJ, 2012.

Mendonça, Joseli Maria Nunes. Entre a mão e os anéis. A lei dos sexagenários e os caminhos da abolição no Brasil. Campinas: Editora da Unicamp, 1999.

Miskolci, Richard. "Machado de Assis, o outsider estabelecido". Sociologias 8.15 (2006): 352-377.

Motta, Márcia Maria Menendes. Nas fronteiras do poder: conflito e direito à terra no Brasil do século XIX. Niterói: Arquivo público do Estado do Rio de Janeiro, 1998.

Pena, Eduardo Spiller. Pajens da casa imperial: jurisconsultos, escravidão e a lei de 1871. Campinas: Editora da Unicamp, 2001.

Pereira, Marcelo Pen. "Estratégias do Falso. Realidade possível em Henry James e Machado de Assis". Tese de doutorado em Teoria Literária e Literatura Comparada, Universidade de São Paulo, 2007.

Prado, Solange Faria. "O poder e a luta pela propriedade da terra no Vale do rio Iconha / Piúma: o caso Thomaz Dutton Junior (1870-1906)". Tese de doutorado em História, Universidade Federal do Espírito Santo, 2018.

Ramos, Ana Flávia Cernic. As máscaras de Lélio: política e humor nas crônicas de Machado de Assis (1883-1886). Campinas: Editora da Unicamp, 2016.

Rocha, Gilda. Imigração estrangeira no Espírito Santo, 1847-1896.Vitória: [s.n.], 2000.

Rodrigues, Pedro Parga. “A experimentação literária de Machado de Assis e o tema da propriedade da terra no XIX”. Revista Cantareira 28 (2018): 101-112. . "A Lei de Terras de 1850 e os Relatórios do Ministério da Agricultura entre 1873-1889”. Revista Maracanan 17 (2017): 103-117. Doi: $10.12957 /$ revmar.2017.27435.

Salles, Ricardo Henrique. "O Império do Brasil no contexto do século XIX. Escravidão nacional, classe senhorial e intelectuais na formação do Estado”. Almanack 4 (2012): 5-45. Doi: 10.1590/2236-463320120401.

Santiago, Silviano. Uma literatura nos trópicos. Ensaios sobre dependência cultural. Rio de Janeiro: Rocco, 2000.

Secreto, María Verónica. "Novas perspectivas na história da escravidão”. Tempo 
22.41 (2016): 442-450.

Silva, Márcio Antônio Both da. "Lei de Terras de 1850: lições sobre os efeitos e os resultados de não se condenar 'uma quinta parte da atual população agrícola””. Revista Brasileira de História 35.70 (2015): 87-107. Doi: 10.1590/1806-93472015v35n70014.

Silveira, Daniela Magalhães da. Fábrica de contos: ciência e literatura em Machado de Assis. Campinas: Editora da Unicamp, 2010.

Tatim, Janaína e Antônio Marcos V. Sanseverino. "A experimentação de Machado de Assis e a sedimentação dos gêneros literários". Todas as Musas 4.2 (2013): 183-199. 